\title{
IMPROVEMENT OF AN IN-HOUSE ELISA FOR BOVINE PARATUBERCULOSIS SEROLOGY IN BRAZIL
}

\author{
Carla Dray Marassi ${ }^{1}$; Leila de Souza Fonseca ${ }^{2}$; Paula Ristow $^{1}$; Rachel Ferreira ${ }^{3}$; Walter Lilenbaum ${ }^{3}$; \\ Walter M.R. Oelemann*1
}

${ }^{1}$ Instituto de Microbiologia, Departamento de Imunologia, Universidade Federal do Rio de Janeiro, Rio de Janeiro, RJ, Brasil; ${ }^{2}$ Departamento de Microbiologia Médica, Universidade Federal do Rio de Janeiro, Rio de Janeiro, RJ, Brasil; ${ }^{3}$ Departamento de Bacteriologia, Universidade Federal Fluminense, Niterói, RJ, Brasil.

Submitted: August 10, 2004; Returned to authors for corrections: November 11, 2004; Approved: April 07, 2005

\begin{abstract}
Paratuberculosis (Johne's disease) is a chronic enteritis in cattle caused by infection with Mycobacterium avium subsp. paratuberculosis (Map). In Brazil, few reports describe the isolation of the organism. The gold standard test for Map is its isolation from tissues or feces. Moreover, bacterial growth is slow and test results are available only after three to five months of incubation Furthermore, shedding of bacilli at levels detectable by fecal culture is irregular and does not occur during the early stages of infection, which compromises the sensitivity of this methodology. The most common immunological tests to identify Map infection are complement fixation test (CFT), agar gel immunodiffusion (AGID) and enzyme-linked immunoassay (ELISA). In Brazil, commercial ELISA kits are imported and too expensive to be used as part of diagnostic laboratorial routine. Apart from that, their use has not yet been approved in the country. The aim of the present study was to improve an original assay PPA-ELISA protocol established by our group, and to determine sensitivity and specificity of the modified test. In a first step, we introduced modifications that minimized plate-to-plate and between-well variations, thus making the test more stable and reliable. In the second part of this study, a panel of 106 sera samples was tested by this modified PPA-ELISA protocol in order to estimate its sensitivity and specificity. The new assay presented overall sensitivity of $76.9 \%$ and specificity of $70.0 \%$. Our study demonstrated that this assay could be recommended as a valuable tool for diagnosis and control of paratuberculosis in Brazil and other developing countries.
\end{abstract}

Key words: paratuberculosis, cattle, ELISA, serology, diagnosis

\section{INTRODUCTION}

Paratuberculosis (Johne's Disease) is characterized by chronic enteritis as consequence of Mycobacterium avium subsp. paratuberculosis (Map) infection in cattle. In Brazil, few reports describe the isolation of this organism. A recent seroepidemiological study carried out in the state of São Paulo determined $37.9 \%$ reactivity in 403 animals tested by a commercial enzyme-linked immunosorbent assay (ELISA). In the state of Rio de Janeiro, a commercial ELISA was used to test 1004 animals from 45 herds. In this study, 18\% of the animals, which were distributed over $82 \%$ of the herds, were reactive (9).

The gold standard test for Map detection is its isolation from tissues or feces. Moreover, bacterial growth is slow, and test results are available only after three to five months of incubation. Furthermore, shedding of bacilli at levels detectable by fecal culture is irregular and does not occur during the early stages of infection, thus diminishing the sensitivity of this methodology (14).

*Corresponding Author. Mailing address: Instituto de Microbiologia, Departamento de Imunologia - UFRJ, Caixa Postal 68040, Cidade Universitária. 21944-970, Rio de Janeiro, RJ, Brasil. Tel.: (+5521) 2270-0990, Fax: (+5521) 2560-8344. E-mail: oelemann@micro.ufrj.br 
The most common immunological tests to identify Map infection are the complement fixation test (CFT), agarose gel immunodiffusion (AGID), and ELISA. AGID can reach 100\% of specificity, but it is less sensitive than the ELISA(11). In Brazil, Ferreira et al. (10) reported a sensitivity of $85.7 \%$ and a specificity of $73.5 \%$. The authors recommend the assay as a valuable tool for the diagnosis of the infection in clinically suspect animals. ELISA-based methods show the highest sensitivity of serological tests for paratuberculosis, since these assays are capable to detect small amounts of antibodies. On the other hand, ELISA is less specific than fecal culture (4) and, therefore, not recommended as a unique diagnostic tool. However, in Brazil, ELISA, has been recommended as screening test for herds (10).

In Brazil, commercial ELISA kits have to be imported and are too expansive to be used as part of national routine in laboratory diagnosis. Furthermore, the Brazilian authorities have not yet approved their utilization. Therefore, it is important to develop diagnostic tests that are highly specific and able to identify infected animals in the early stages of the disease. Besides, these assays must be adapted to the epidemiological conditions of the country. The ELISA-PPA protocol described by Ferreira et al. (10) uses PPA (paratuberculosis protoplasmic antigen) as capture antigen. The assay is easy to perform and has been considered as a good screening test for identifying infected herds. However, its accuracy as well as its sensitivity and specificity need to be improved. Although ELISAs using PPA as antigen are extensively used in other countries $(10,15,16)$, the protocol described by the authors (9) showed low reproduction (high between-well and plate-to-plate variation).

The aim of the present study was to improve the original PPA-ELISA (10) and determine the sensitivity and specificity of the modified test.

\section{MATERIALS AND METHODS}

\section{Experiments}

The study was conducted in two steps: In a first step, we introduced important alterations in the ELISA-PPA test protocol (10) to improve reproducibility of the results and to reduce between-well and plate-to-plate variations. The modifications are described below and all tests were performed by using six positive and four negative control sera obtained from culturepositive and culture-negative animals, respectively (kindly provided by Prof. Michael Collins, Wisconsin University USA). After standardization of the new protocol, the test was submitted to a second step using a panel of 106 serum samples in order to evaluate its sensitivity (positive sera) and specificity (negative sera).

\section{Serum samples}

A panel of serum samples obtained from 106 dairy adult animals from herds maintained in the state of Rio de Janeiro was used. Sera were divided into two categories and four groups. Category 1 comprised positive sera and was used to determine the sensitivity of the test. This category is composed by group A, which included 13 sera from animals with positive fecal culture, and group B, composed by sera of 13 animals without culture results, but which were reactive in two different commercial ELISAs (Parachek-CSL, HerdCheck-Idexx, IDDEX Lab. - USA) and one in-house ELISA-PPA (antigen obtained from Allied Monitor, USA). Category 2 consisted of negative sera and was used to determine the specificity of the test. This category was composed by Group C, which included 39 sera from animals with negative fecal culture, and group $\mathrm{D}$, which included 41 sera from animals of herds with no history of paratuberculosis and non reactive in a commercial ELISA assay (Parachek-CSL).

\section{Original ELISA-PPA protocol}

Sera were tested by ELISA-PPA as previously described (10). Briefly, PPA (Allied Monitor, USA) was used as a capture antigen, which was adsorbed in a 96-well plate (Nunc Maxisorb, Nunc, Dennmark). Each well was coated overnight with $100 \mu \mathrm{L}$ of antigen solution $(10 \mathrm{mg} / \mathrm{mL})$ at room temperature and blocked with $2 \%$ gelatin in TBST (Tris $10 \mathrm{mM}, 0.09 \% \mathrm{NaCl}, 0.2 \%$ Tween 20). Each serum sample was mixed with an equal volume of $M$. phlei extract $(5 \mathrm{mg} / \mathrm{mL})$ and absorbed at room temperature for one hour. After centrifugation, the pre-adsorbed sera were added to the wells and incubated for one hour at room temperature. A monoclonal anti-bovine $\operatorname{IgG}$ antibody conjugated to alkaline phosphatase was used. Immune complexes were detected by addition of $\mathrm{p}$ NPP substrate (Sigma-Aldrich, USA) $(1 \mathrm{mg} / \mathrm{mL}$ ) and incubation for 15 minutes at room temperature. Three wash steps with TBST were included after incubation with first and second antibody. Sera were tested at the dilution 1:100 and all assays were run in duplicate. Any assay with a between-well coefficient of variation of $>15 \%$ was repeated. The samples optical density (OD) was measured at 405nm (Model 680, Bio-Rad, USA).

\section{Tests modifications}

The original protocol was modified in order to improve its reproducibility and to minimize the between-well and plate-toplate variation. PPA was diluted in carbonate buffer and sonicated for one minute with a 75-W cell disruptor (Microson ${ }^{\circledR}$ Sonicator VCX 400W). The plates were coated overnight with the antigen at $8^{\circ} \mathrm{C}$. Casein ( $2 \%$ in TBST) was used during the blocking step. M. phlei was mixed with an equal volume as the serum samples for 60 minutes with constant agitation at $37^{\circ} \mathrm{C}$. After that, M. phlei- serum suspension was incubated overnight at $8^{\circ} \mathrm{C}$. All sera were tested in three different dilutions: $1: 100$, $1: 200$ and 1:400. The optical density (OD) at of $405 \mathrm{~nm}$ was recorded (BioRad - Model 680). In order to compare original and modified ELISA-PPA in-house protocols, the same cut-off point of the original assay $(0.350)$ was adopted for the modified 
test. Furthermore, to allow for comparison of results obtained at different days on different plates, final results were expressed as $\mathrm{S} / \mathrm{P}$ ratio, which was obtained by dividing the mean $\mathrm{OD}$ value (S) of a given serum by the mean OD value $(\mathrm{P})$ of the positive control. Sera were classified as positive when their S/P value were equal or higher than 0.35 .

\section{RESULTS AND DISCUSSION}

Several modifications in the protocol, as the substitution of gelatin by casein or reducing the incubation time for each step to 30 minutes, did not alter the results significantly. The most valuable alterations, which improved the results, were the antigen sonication and the overnight coating of the plate at $8^{\circ} \mathrm{C}$. These steps intend to allow a greater exposure of PPA epitopes, which could contribute to minimize the between-well coefficient variation to less than $15 \%$. Preadsorption of the sera with $M$. phlei is known to improve ELISA specificity, since it reduces the occurrence of cross-reactive results $(17,18)$. The constant agitation at $37^{\circ} \mathrm{C}$ of the plate during preadsorption probably facilitated the immune interactions between $M$. phlei antigens and unspecific antibodies. The modified protocol reduced between-well and plate-to-plate variations, making the test more stable and reliable. Results obtained for control sera employing the original and the modified assay are depicted in Fig. 1.

In a second step, 106 sera samples were tested by the modified PPA- ELISA protocol, in order to estimate its sensitivity and specificity. Firstly sensitivity was estimated using two groups of positive samples, a group (A) confirmed by culturing and recovery of Map and a group (B) of serologically reactive samples. From 13 animals of group A, nine (69.2\%) were reactive and from 13 sera of group B ten $(76.9 \%)$ were reactive. The overall reactivity of the category 1 sera was $19 / 26$, which means that $73 \%$ of the positive animals, either by culture or by serological tests, were correctly identified by this assay.

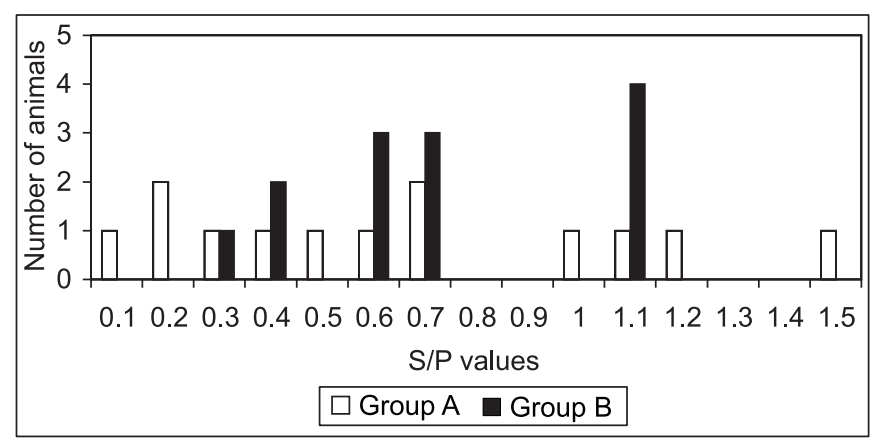

Figure 1. Histogram showing the $S / P$ values of sera tested by ELISA-PPA, using a cut-off value of 0.350 (OD 405nm). Group A culture positive animals, $n=13$; group $B$ serologically reactive animals, $\mathrm{n}=13$.
Only three animals of group A presented clinical signs of the disease. Sera of those animals presented high S/P values, greater than the positive control serum. The other ten animals were asymptomatic, including the four cows that were not detected by our ELISA. In the present study, all animals with clinical signs of paratuberculosis were correctly identified, as well as six of the ten asymptomatic shedding animals. Our findings agree with those reported by Stabel et al. (19), who report that humoral response tends to increase during the evolution of the infection, and can frequently be observed before the appearance of clinical signs. A commercial ELISA employing sera preadsorbed with $M$. phlei detected only $50 \%$ of infected cattle older than two years (12) and, when compared to culture, presented a sensitivity of $49 \%$ (14). The identification of $60 \%$ of asymptomatic shedding animals by our modified protocol is consistent with the findings of others (7) that some infected animals seroconvert after becoming shedders, while other animals first shed the bacteria and then undergo seroconversion. Thus, it is unpredictable whether infected animals will yield a positive test result first by fecal culture or by $\operatorname{ELISA}(7)$.

In animals from group B, ten of the 13 samples (76.9\%) were correctly identified. Three sera showed false-negative results in the PPA-ELISA. Ferreira et al. (10) compared the original inhouse PPA-ELISA protocol with commercial assays and observed a weak correlation between the tests. The authors argue that, since the PPA-ELISA uses a different antigen than the commercial tests, it detects distinct subsets of infected animals at different moments in the evolution of the infection.

The modified PPA-ELISA had an overall sensitivity of $76.9 \%$, similar to the sensitivity values reported by other investigators $(4,5,6,9,11)$. This finding suggests that the spectrum of the disease of our animals was at least comparable to that of animals typically used for paratuberculosis serologic test evaluation (5). In paratuberculosis, the humoral response tends to increase mainly during the late stages of the infection, when clinical symptoms occur $(3,16)$. Since most of the samples in our panel

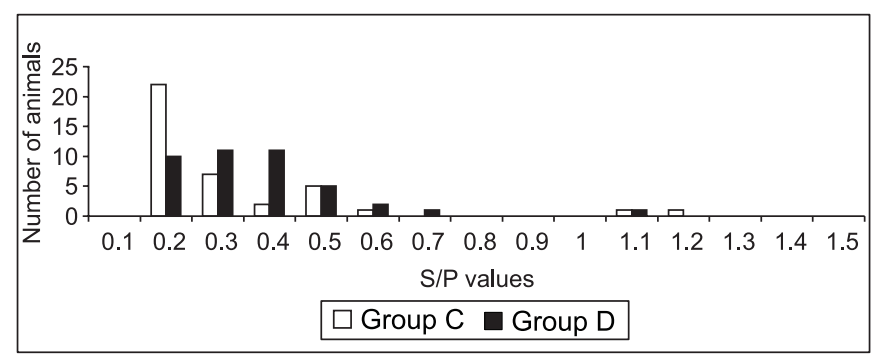

Figure 2. Histogram showing the $\mathrm{S} / \mathrm{P}$ values of sera tested by ELISA-PPA, using a cut-off value of 0.350 (OD 405nm). Group C culture negative animals, $n=39$; group $D$ serologically nonreactive animals, $\mathrm{n}=41$. 
originated from asymptomatic animals, it is possible that their antibody titers were still undetectable by our assay.

The specificity of our protocol was calculated by using two groups of negative samples: group $\mathrm{C}$ were sera from culturenegative animals, and group $\mathrm{D}$ were serologically non-reactive samples obtained from herds with no history of the disease. From the 39 animals of group C, 30 (76.9\%) were non-reactive, and from the 41 sera of group D 26 (63.4\%) were confirmed as non-reactive. The overall reactivity of sera from category 2 was $24 / 80$, which means that $70 \%$ of the negative animals were correctly identified by this assay and confirmed as non-reactive.

The low specificity of our assay in spite of the preadsorptionstep with $M$. phlei, which intends to eliminate cross-reactive antibodies raised against environmental mycobacteria was surprising. No attempt was made to measure and reduce the occurrence of possible cross-reaction caused by antibodies against $M$. bovis. The interference of paratuberculosis antibodies in diagnostic tests for bovine tuberculosis is a welldocumented phenomenon (13). Olsen et al. (15) reported that the specificity of commercial assays for paratuberculosis is very low and alerts that the capacity of these tests to differentiate between paratuberculosis and bovine tuberculosis have not been evaluated. Although all animals tested were negative by intradermal tuberculosis tests, the disease still occurs in Brazil. Animals are frequently tested by injection of PPD antigens and the real immune status of the animals with regard to mycobacteria and the possible interference of antibodies in diagnostic assays for paratuberculosis remain uncertain. Therefore, further studies using specific antigens that reliably differentiate between anti-M. bovis and anti-Map antibodies are imperative for the control of the two diseases in developing countries where both infections may occur simultaneously.

Due to its high sensitivity, the PPA-ELISA protocol described here can be recommended as a screening test for identification of paratuberculosis foci. Coccito et al. (3) estimate that for each animal with clinical disease, nine other animals in the herd are culture positive and another 10 to 15 animals may be infected but remain undetected by current diagnostic methods. As much as $60 \%$ of certain herds were reported to be asymptomatically infected (3) therefore, a screening test capable to identify suspect and serological reactive asymptomatic animals is needed. The results presented here indicate that the PPA-ELISA assay can be used as a valuable tool for diagnosis and control of paratuberculosis in Brazil and other developing countries.

\section{ACKNOWLEDGEMENTS}

WMRO, LSF, RF and WL are research fellows of the Conselho Nacional de Pesquisa (CNPq), CDM is a PhD fellow funded by CNPq. Financial support was provided by Fundação de Amparo à Pesquisa Carlos Chagas Filho, FAPERJ and CNPq/Instituto do Milênio.

\section{RESUMO}

\section{Desenvolvimento de um teste ELISA in-house para diagnóstico de paratuberculose em boninos no Brasil}

Paratuberculose (doença de Johne) se caracteriza por uma enterite crônica de ruminantes, causada por Mycobacterium avium subesp. paratuberculosis (Map). O padrão ouro diagnóstico da infecção é a cultura e isolamento do microrganismo a partir de tecidos ou fezes. No entanto, seu crescimento demora de três a cinco meses e a excreção de Map em níveis detectáveis em cultura é irregular e não ocorre durante os primeiros estágios da infecção, o que diminui seus níveis de sensibilidade. No Brasil, existem poucos relatos de seu isolamento. Os testes imunológicos mais comuns para a identificação da infecção são: Fixação de complemento, imunodifusão em gel de agarose e ensaio imunoenzimático do tipo ELISA. No Brasil, kits comerciais ELISA de diagnóstico são importados e seu uso não está ainda aprovado. O objetivo deste estudo é melhorar um ensaio ELISA-PPA in-house previamente desenvolvido (10) e determinar sua sensibilidade e especificidade. Na primeira etapa deste estudo, as alterações do protocolo original contribuíram para diminuir as variações encontradas entre poços na mesma placa e entre placas em experimentos diferentes, o que demonstrou uma maior estabilidade e reprodutibilidade do teste. Na segunda etapa, um painel de 106 amostras de soros foi testado pelo protocolo modificado do ELISA-PPA para estimar seus índices de sensibilidade e especificidade. O ensaio apresentou sensibilidade de $76,9 \%$ e especificidade de $70,0 \%$. Nosso estudo demonstrou que este ensaio pode ser recomendado como uma valiosa ferramenta para diagnóstico e controle da paratuberculose no Brasil e em outros países em desenvolvimento.

Palavras-chave: paratuberculose, bovinos, ELISA, sorologia, diagnóstico.

\section{REFERENCES}

1. Adaska, J.M.; Anderson R.J. Seroprevalence of Johne's disease infection in dairy cattle in California, USA. Prev. Vet. Med., 60, 255 261, 2003

2. Anonymous. A Guide to Johne's Disease in Austrália. National Johne's Disease Program. Australian Animal Health Council ltd., 2001.

3. Cocito, C.; Gilot, P.; Coene, M.; De Kesel, M.; Poupartet, P.; Vannuffel, P. Paratuberculosis. Clin. Microbiol. Rev., 7, 328- 345, 1994.

4. Collins, M.T. Diagnosis of Paratuberculosis. Vet. Clin. North Am. Food Animal Pract., 12, 357-371, 1996.

5. Collins, M.T. Interpretation of a commercial Bovine Paratuberculosis Enzyme-linked Immunosorbent Assay by Using Likelihood Ratios. Clin. Diagn. Lab. Immunol., 9, 1367-1371, 2002.

6. Cox, J.C.; Drane, D.P.; Jones, S.L.; Ridge, S.; Milner, A.R. Development and evaluation of a rapid absorbed enzyme 
immunoassay test for the diagnosis of Johne's disease in cattle. Austr. Vet. J., 68: 157- 160, 1991.

7. El-Zaatari, F.A.K.; Hulten, K.; Collins M.T.; Huchzeimeier R.; Graham D.Y. P-35- based assay for the detection of Mycobacterium paratuberculosis infection in cattle with Johne's Disease. Proc. Seventh Int. Coll. Paratuberculosis., 136-139, 2002.

8. Ferreira, R.; Fonseca, L.S.; Lilenbaum, W. Agar gel immunodiffusion test (AGID) evaluation for detection of bovine paratuberculosis in Rio de Janeiro, Brazil. Lett. Appl. Microbiol., 35, 173-5, 2002

9. Ferreira, R.; Fonseca, L.S.; Lilenbaum, W. Comparison between a commercial and an in-house ELISA for anti- $M$. avium paratuberculosis antibodies detection in dairy herds in Rio de Janeiro, Brazil. Rev. Lat. Microbiol., 44, 129-132, 2002.

10. Ferreira, R; Fonseca L.S.; Lilenbaum W. Detecção de anticorpos contra Mycobacterium paratuberculosis em rebanhos bovinos do Estado do Rio de Janeiro, Brasil. Rev. Bras. Med. Vet., 23, 166-171, 2001.

11. Harris, B.N.; Barletta, R.G. Mycobacterium avium subsp. paratuberculosis in Veterinary Medicine. Clin. Microbiol. Rev., 14, 489-512, 2001.

12. Jubb, T.; Galvin, J. Herd Testing to control bovine Johne's Disease. Vet. Microb., 77, 423-428, 2000.

13. Kohler, H.; Gyra, H.; Zimmer, K.; Drager, K.G.; Burket, B.; Lemser, B.; Hauslethener, D.; Cubler, K.; Klawnonn, W.; Hrb, R.G. Immune Reactions in Cattle after Immunization with a Mycobacterium paratuberculosis vaccine and Implications for the Diagnosis of $M$. paratuberculosis and M. bovis Infections. J. Vet. Med. B., 48, 185195, 2001.

14. McNab, W.B.; Meek, A.H.; Duncan R.J.; Brooks B.W.; Van Dreumel, A.A.; Martin S.W.; Nielsen K.H.; Sugden E.A.; Tureotte, C. An Evaluation of selected screening tests for bovine paratuberculosis. Canad. J. Vet. Res., 55, 252-259, 1991.

15. Olsen, I.; Tryland, M.; Wiker, H.G.; Reitan, L.J.; AhpC, AhpD and a secreted $14 \mathrm{Kda}$ antigen from Map distinguish between paratuberculosis and bovine tuberculosis in an ELISA assay Clin. Diag. Lab. Immunol., 8, 797- 803, 2001.

16. Paolicchii, F.A.; Zumarraga, M.J.; Gioffre, A.; Zamorano, P.; Morsella, C.; Verna, A.; Cataldi, A.; Alito, A.; Romano, M. Application of different methods for the diagnosis of paratuberculosis in a dairy cattle herd in Argentina J. Vet. Med. B., 50, 20-26, 2003.

17. Ristow, P. Avaliação de Métodos de Cultivo e da Reação de Polimerase em Cadeia na Detecção de Mycobacterium avium paratuberculosis para o Diagnóstico de Paratuberculose Bovina. Rio de Janeiro, 2004, 140p. (M.S. Dissertação. Instituto de Microbiologia Prof. Paulo Goés, UFRJ).

18. Stabel, J.R. Transitions in Immune Responses to Mycobacterium avium paratuberculosis. Vet. Microbiol., 77, 465-473, 2000.

19. Socket, D.C.; Conrad, T.A.; Thomas, C.B.; Collins, M.T. Evaluation of four serological tests for bovine paratuberculosis. J. Clin. Microbiol., 30: 1134-1139, 1992. 